\title{
Article \\ Spray and Aerosolised pH-Neutral Electrochemically Activated Solution Reduces Salmonella Enteritidis and Total Bacterial Load on Egg Surface
}

\author{
Sangay Tenzin ${ }^{1}$, Sergio Ferro ${ }^{2}\left(\mathbb{D}\right.$, Samiullah Khan ${ }^{3} \mathbb{C}$, Permal Deo ${ }^{4, *} \mathbb{C}$ and Darren J. Trott ${ }^{1, *}$ \\ 1 Australian Centre for Antimicrobial Resistance Ecology, School of Animal and Veterinary Sciences, \\ The University of Adelaide, Mudla Wirra Rd, Roseworthy 5371, Australia; sangay.tenzin@adelaide.edu.au \\ 2 Ecas4 Australia Pty. Ltd., Unit 8/1 London Road, Mile End South 5031, Australia; sergio@ecas4.com.au \\ 3 School of Animal and Veterinary Sciences, The University of Adelaide, Roseworthy 5371, Australia; \\ samiullah.khan@adelaide.edu.au \\ 4 Health and Biomedical Innovation, UniSA Clinical and Health Sciences, University of South Australia, \\ Adelaide 5000, Australia \\ * Correspondence: permal.deo@unisa.edu.au (P.D.); darren.trott@adelaide.edu.au (D.J.T.)
}

Citation: Tenzin, S.; Ferro, S.; Khan, S.; Deo, P.; Trott, D.J. Spray and Aerosolised $\mathrm{pH}-\mathrm{Neutral}$

Electrochemically Activated Solution Reduces Salmonella Enteritidis and Total Bacterial Load on Egg Surface. Appl. Sci. 2021, 11, 732. https://doi. org/10.3390/app11020732

Received: 21 December 2020 Accepted: 11 January 2021 Published: 13 January 2021

Publisher's Note: MDPI stays neutral with regard to jurisdictional clai$\mathrm{ms}$ in published maps and institutional affiliations.

Copyright: (C) 2021 by the authors. Licensee MDPI, Basel, Switzerland. This article is an open access article distributed under the terms and conditions of the Creative Commons Attribution (CC BY) license (https:// creativecommons.org/licenses/by/ $4.0 /)$.

\begin{abstract}
The effectiveness of sprayed and aerosolised pH-neutral electrochemically activated solutions (ECAS) containing $150 \mathrm{mg} / \mathrm{L}$ of free available chlorine in reducing total bacteria load and artificially inoculated Salmonella enterica serotype Enteritidis 11RX on eggs surfaces was investigated. Treatment groups included untreated control, sodium hypochlorite (positive control), sprayed and aerosolised water and sprayed and aerosolised ECAS. Sprayed ECAS (150 mg/L, $45 \mathrm{~s})$ showed a significant reduction in total bacterial load $(2.2 \log$ reduction, $p<0.0001)$ and $S$. Enteritidis $(5.4 \log$ reduction, $p<0.0001$ ) when compared with the untreated control. Aerosolised ECAS (120 s) was effective in reducing both the total bacterial load $(1.4 \log$ reduction, $p<0.01)$ and $S$. Enteritidis $(4.2 \log$ reduction, $p=0.0022)$. However, aerosolised ECAS (60 s) only significantly reduced $S$. Enteritidis counts $(2.8 \log$ reduction, $p<0.0008)$, indicating that a longer time for bacterial reduction during fogging sanitisation is needed. Tests performed with one egg per oscillating tray were more effective in reducing both the total bacterial load and the $S$. Enteritidis counts than those with three eggs per oscillating tray. Sprayed ECAS (45 s) and aerosolised ECAS (120 s) did not deteriorate the egg cuticle integrity $\left(\Delta E_{\mathrm{ab}}{ }^{*}\right)$, which was evaluated using Cuticle Blue dye solution and colour intensity measurement. Overall, both the reduction in total bacteria counts and $S$. Enteritidis from the egg surface and retention of cuticle integrity suggest that sprayed and aerosolised ECAS could be used as alternative sanitising approaches to improve the food safety aspect of table eggs.
\end{abstract}

Keywords: pH-neutral electrochemically activated solution; total bacterial count; Salmonella Enteritidis; egg cuticle integrity

\section{Introduction}

Pathogenic serotypes of Salmonella are a major cause of foodborne diseases worldwide. The annual proportion of food origin salmonellosis in Australia is about 40,000 out of an estimated total of about 4.1 million foodborne gastroenteritis cases [1]. Salmonella- associated foodborne illnesses have risen during the past 20 years and the rate of salmonellosis in Australia is much higher compared to economically similar countries [2]. It has been estimated that foodborne illnesses due to Salmonella spp. have caused up to $35 \%$ of hospitalisations and $28 \%$ of mortalities [1], and the hospitalisation and death cases were higher in comparison to other foodborne illnesses [1]. Among the salmonellosis cases of foodborne origin, raw eggs and egg-based products have the highest frequency [3-5]. For example, between 2001 and 2016, 50\% of all foodborne Salmonella illnesses in Australia were attributed to the consumption of contaminated eggs [6]; $84 \%$ of these cases were caused by Salmonella enterica subspecies enterica serotype Typhimurium (S. Typhimurium) and three cases were 
caused by Salmonella enterica subspecies enterica serotype Enteritidis (S. Enteritidis) [6]. In other countries, salmonellosis is caused predominantly by the serotype Enteritidis [7-9]. As egg consumption in Australia is approx. 245 eggs per capita and growing [10], the industry is continuously exploring alternative means to address Salmonella contamination.

Unlike the one-off input costs for the establishment of farm infrastructure and human resources, farms and industries incur ongoing costs for egg hygiene and egg safety management. Washing and disinfection of egg surface are the key steps involved in egg production to reduce the risk of egg-related foodborne illnesses and to maintain consumer confidence on the microbiological safety of eggs. Elimination of pathogenic bacteria from the egg surface is achieved using several techniques and many eggshell sanitisation methods are also employed to reduce the contamination of eggs by Salmonella in commercial egg production premises.

Protocols employed for the reduction of Salmonella can be broadly classified into thermal and non-thermal disinfection procedures. Thermal disinfection, such as egg pasteurisation, is a highly effective method, but negatively affects egg proteins and rheological properties [11]. The most common non-thermal processes employ quaternary ammonium compounds (QAC) and chlorine-based chemicals [12] to sanitise eggs after washing with a high $\mathrm{pH}$ (11.0) detergent solution at a temperature above $40{ }^{\circ} \mathrm{C}$. Unfortunately, bacteria may develop resistance to QAC [13], which in turn induces selection of genes for co-resistance to other antimicrobials [14], thus limiting its use. In the case of chlorine-based sanitisers, besides the development of bacterial resistance due to its persistent usage [15], the accumulation of organic load from dirt, manure and broken eggs reduces the chlorine concentration, affecting the efficacy of chlorine-based sanitisation. Moreover, due to the environmental impact caused by chlorine-based by-products and the problems with wastewater disposal, its usage in the food industry is limited. Other decontamination methods used are ultraviolet (UV) irradiation of eggs after washing and formaldehyde fumigation. However, the antibacterial activity of UV irradiation protocol is limited to the egg surface directly exposed to UV rays [16], while formaldehyde is a known occupational health hazard and a carcinogenic product [17].

Since occupational health safety and environmental regulations continually push towards safer eggshell sanitisers, electrochemically activated solutions (ECAS) (also called electrolysed oxidizing (EO) water) could be a potential alternative for eggshell cleaning and disinfection. The three forms of ECAS (acidic, slightly acidic and neutral) have been previously assessed for the sanitisation of table eggs in safe food production [18-21] and fertile eggs for quality production of chicks [22]. In most of the available research, a twostep process for ECAS disinfection of eggs was followed. In the initial washing step, dirt and debris are washed off the egg surface with water or alkaline detergent, followed by the ECAS disinfection. Bialka et al. [19] reported that immersion washing of eggs with acidic ECAS significantly reduced $S$. Enteritidis and Escherichia coli from the egg surface but also damaged the egg cuticle layer. On the other hand, the spray washing of eggs with slightly acidic EO water reduced total aerobic bacteria without negatively affecting the cuticle layer [22]. In other studies, an immersion washing with pH-neutral ECAS was not effective in reducing the total bacterial load [23], while a spray wash significantly decreased the level of Listeria monocytogenes without affecting the egg cuticle layer [20]. More recently, Medina-Gudino et al. [24] reported that $\mathrm{pH}$-neutral EO spray treatment for $30 \mathrm{~s}$ significantly reduced $S$. Enteritidis and E. coli loads on the egg surface without adversely affecting egg cuticle integrity.

In this study, we explored the potential of $\mathrm{pH}$-neutral ECAS $(150 \mathrm{mg} / \mathrm{L}$ of free available chlorine (FAC)) as spray and aerosol fog for the sanitisation of unwashed, visibly clean eggs, assessing the reduction in total bacterial counts and Salmonella Enteritidis, and its effects on the cuticle layer. ECAS with neutral $\mathrm{pH}$ still contains hypochlorous acid $(\mathrm{HOCl})$ as the main oxidising component (active chlorine compounds also include hypochlorite ions and dissolved gaseous chlorine) [25-27] but is less corrosive and more durable than the acidic and slightly acidic forms. 


\section{Materials and Methods}

\subsection{Chicken Egg Source and Selection}

Freshly laid eggs were sourced from Hy-Line Brown hens (aged between 36 and 40 weeks) raised in conventional battery cages housing individual hens at the School of Animal and Veterinary Sciences, The University of Adelaide. Eggs stored for $24 \mathrm{~h}$ at room temperature were visually screened for thermal cracks and dirt; relatively clean, intact and uniformly sized eggs were selected and randomly divided into groups to determine the effectiveness of sanitisation treatments on total microbial load and artificially inoculated $S$. Enteritidis load.

\subsection{ECAS Spray and Fog Disinfection Generation}

The electrochemically activated solution was sourced from Ecas4 Australia Pty Ltd. (Adelaide, Australia) and its physicochemical properties such as temperature, $\mathrm{pH}$, and oxidation/reduction potential (ORP) were measured using a handheld meter (Model MC80, TPS Pty Ltd., Brisbane, Australia). Free and total available chlorine was measured using a Free Chlorine Checker ${ }^{\circledR}$ HC-HI701 and a Total Chlorine Checker ${ }^{\circledR}$ HC-HI711 (Hanna Instruments, Melbourne, Australia), respectively. ECAS was stored at $4 \pm 1{ }^{\circ} \mathrm{C}$ and used within one week of preparation.

The working concentration of ECAS $(\mathrm{pH} \approx 6.8-7.0,150 \mathrm{mg} / \mathrm{L}$ of free available chlorine (FAC)) was freshly prepared each time prior to sanitisation experiment. We have previously optimised the aerosolised ECAS at $150 \mathrm{mg} / \mathrm{L}$ of FAC to significantly reduce the total microbial load in an animal farm environment, and for this reason we have chosen this concentration [28]. For the spray wash, ECAS was sprayed for $45 \mathrm{~s}$ using a handheld bottle sprayer. For the fog sanitisation, ECAS fog was generated using an ultrasonic humidifier that generates droplets sized between 1 and $3 \mu \mathrm{m}$ in diameter (Ultrasonic Humidifier HU-85, Contronics Engineering B.V., Sint-Oedenrode, The Netherlands) as previously optimised [28].

\subsection{Effectiveness of Spraying and Fogging on Total Bacterial Load Reduction on Eggshell Surface}

For total bacterial counts, intact and visibly clean eggs were selected for each of the treatment groups (three eggs per treatment): unwashed control, $\mathrm{NaOCl}$ spray ( $200 \mathrm{mg} / \mathrm{L}$ of FAC, positive control), water spray ( $45 \mathrm{~s})$, ECAS spray ( $150 \mathrm{mg} / \mathrm{L}$ of FAC; $45 \mathrm{~s})$, water fog $(60$ and $120 \mathrm{~s})$ and ECAS fog $(150 \mathrm{mg} / \mathrm{L}$ of FAC; 60 and $120 \mathrm{~s})$. The disinfection procedures were performed in a biosafety cabinet (BSC) and eggs were placed in separate compartments on an oscillating tray for uniform exposure during spray-wash and fogging treatment. Each treatment was independently repeated for at least two times. In addition, ECAS (150 mg/L of FAC) fog treatment was compared for one and three eggs per oscillating tray, for $60 \mathrm{~s}$ and $120 \mathrm{~s}$, respectively.

After treatment, individual eggs were immediately placed into a sterile Whirl-Pak bags (Nasco, Fort Atkinson, WI, USA) containing $5 \mathrm{~mL}$ of buffered peptone water (BPW), massaged gently (without breaking the egg) for $1 \mathrm{~min}$, then the broth was transferred into $10 \mathrm{~mL}$ sterile tubes (SARSTEDT Australia Pty Ltd., Adelaide, Australia). Samples were centrifuged at $5444 \times g$ (MPW-351e Centrifuge, Med Instruments, Adelab Scientific, Adelaide, Australia) for $10 \mathrm{~min}$, supernatant discarded, and the pellet was resuspended in $200 \mu \mathrm{L}$ of $1 \times$ PBS. Aliquots (100 $\mu \mathrm{L}$ ) of 10 -fold dilutions (up to $10^{-5}$ ) of the samples were spread plated on plate count agar (PCA; CM0325, Oxoid, Melbourne, Australia) in duplicates and incubated overnight at $37^{\circ} \mathrm{C}$ for the enumeration of colonies. Plates with 25 to 300 colonies were used for colony forming unit (CFU) calculation and data presented as $\log _{10} \mathrm{CFU} /$ egg.

\subsection{Salmonella Enteritidis Seeding on Outer Eggshell Surface}

\subsubsection{Pre-Wash of Eggs for $S$. Enteritidis Seeding}

To understand the efficacy of ECAS on Salmonella load reduction, eggs selected for Salmonella seeding were washed as per wash steps specified in Gole et al. [29] before being 
inoculated with $S$. Enteritidis. Briefly, eggs were placed on an oscillating tray, which helped in exposing the entire eggshell surface, in a BSC and initially spray-washed with a $0.45 \%(v / v)$ solution of $\mathrm{NaOCl}$ (ThermoFisher, Melbourne, Australia; $\mathrm{pH} \approx 12$ ) at $40{ }^{\circ} \mathrm{C}$ for $45 \mathrm{~s}$. Then, spray-sanitised with a $0.16 \%(\mathrm{v} / \mathrm{v})$ solution of $\mathrm{NaOCl}$ at $32{ }^{\circ} \mathrm{C}$ for $22 \mathrm{~s}$ and left on the sterilised BSC bench to dry for $60 \mathrm{~min}$. The eggs were sanitised to ensure the complete removal of the microbiota of the egg surface and to achieve a uniform $S$. Enteritidis colonisation of the egg surface.

\subsubsection{S. Enteritidis Preparation for Inoculation of Eggshells}

Salmonella Enteritidis 11RX was used for this experiment. S. Enteritidis stored at $-80{ }^{\circ} \mathrm{C}$ in $80 \%$ glycerol was plated on xylose lysine deoxycholate (XLD) agar (Oxoid $\mathrm{CM}$ 0469) and incubated overnight at $37^{\circ} \mathrm{C}$ to obtain isolated colonies. An inoculum was prepared by suspending colonies in phosphate buffered saline $(1 \times$ PBS $)$ to obtain an absorbance $\left(\mathrm{OD}_{600 \mathrm{~nm}}\right)$ value of 0.45 . Viable Salmonella was enumerated by plating 10 -fold serial dilutions of the inoculum on XLD agar and incubating overnight at $37{ }^{\circ} \mathrm{C}$. After enumeration, a $200 \mathrm{~mL}$ inoculum containing $\sim 10^{5} \mathrm{CFU}$ per $\mathrm{mL}$ was prepared in $1 \times$ PBS.

For eggshell seeding, eggs were immersed for $90 \mathrm{~s}$ either in $1 \times \mathrm{PBS}$ (control) or in $1 \times$ PBS containing $\sim 10^{5} \mathrm{CFU} / \mathrm{mL}$ of $S$. Enteritidis. Eggs were then placed into sterile zip lock bags and incubated at $37^{\circ} \mathrm{C}$. After $18-24 \mathrm{~h}$ post-inoculation, three eggs from each treatment were placed in separate Whirl-Pak bags containing $5 \mathrm{~mL}$ BPW and massaged for 1 min. Aliquots $(100 \mu \mathrm{L})$ from a 10-fold serial dilution were spread plated on XLD and PCA media (in duplicate) and incubated overnight at $37^{\circ} \mathrm{C}$ for enumeration of counts.

\subsubsection{Effectiveness of Spraying and Fogging on S. Enteritidis on Eggshell Surface}

The $S$. Enteritidis-inoculated eggs were subjected to the same treatment as above (Section 2.3). A 10-fold serial dilutions were prepared for each treatment as above in $1 \times$ PBS and aliquots were spread plated both on PCA and XLD agar media (in duplicates).

\subsection{Eggshell Cuticle Assessment}

Twelve eggs per each treatment (water and ECAS spray washing for $45 \mathrm{~s}$ and water and ECAS fogging for $2 \mathrm{~min}$ ) were screened and selected based on colour intensity measured using a MiniScan EZ colourimeter (4500 L Spectrophotometer, Hunter Associates Laboratory, Inc., Reston, VA, USA). The selected eggs were treated as in Section 2.3 and dried in biosafety cabinet for $60 \mathrm{~min}$. The eggs were stained with MST Cuticle Blue dye (MS Technologies, Kettering, UK) as described by Khan et al. [30] and the cuticle coverage was assessed using the $\Delta E_{\mathrm{ab}}{ }^{*}$ method. The average of four readings of the $L^{*}$ (lightness), $a^{*}$ (red/green value) and $b^{*}$ (yellow/blue value) values, before and after staining, were used for the calculation of $\Delta E_{\mathrm{ab}}{ }^{*}$ with Equation (1). A higher value of $\Delta E_{\mathrm{ab}}{ }^{*}$ denotes a higher cuticle staining:

$$
\Delta E_{\mathrm{ab}}^{*}=\sqrt{ }\left[\left(\Delta L^{*}\right)^{2}+\left(\Delta a^{*}\right)^{2}+\left(\Delta b^{*}\right)^{2}\right]
$$

\subsection{Statistical Analysis}

Total bacterial and $S$. Enteritidis counts were expressed as $\log _{10} /$ egg and the data were analysed using ANOVA in GraphPad Prism v.8 (GraphPad Software, San Diego, CA, USA). Since the bacterial counts were log transformed (subjected to normal distribution) and each experiment had an equal number of samples, a one-way ANOVA was performed to compare differences of means among untreated control versus different sanitising treatments followed by a Tukey's multiple comparison test. A $p$ value of $<0.05$ was considered statistically significant.

\section{Results}

\subsection{ECAS Spray and Aerosol Treatment Reduced Total Bacterial Count on Egg Surface}

The mean bacterial load $\left(\log _{10}\right.$ CFU/egg) for untreated and after sanitising treatments are presented in Table 1 and Figure 1 . Eggs treated with sprayed water (45 s) $\left(2.4 \pm 0.1 \log _{10}\right.$ 
CFU/egg) showed no significant reduction ( $p=0.3662)$ in total bacterial load when compared with the untreated control $\left(2.2 \pm 0.2 \log _{10} \mathrm{CFU} / \mathrm{egg}\right.$; Table 1). Significant reduction in total bacterial load was observed when the eggs were treated with sprayed ECAS (45 s) (2.2 log reduction, $p<0.0001)$ and aerosolised ECAS (120 s) (1.4 log reduction, $p=0.01$ ) compared to untreated control (Table 1). Aerosolised water ( $60 \mathrm{~s}$ and $120 \mathrm{~s}$ ) and aerosolised ECAS (60 s) showed no significant reduction in total bacterial load when compared with sprayed water (45 s) or the untreated control (Table 1). In addition, the spray versus aerosol techniques were compared for their effectiveness in reducing the total bacterial load (Figure 1A). Sprayed ECAS (45 s) showed a significant reduction $(p<0.0001)$ in total bacterial load when compared with sprayed water (45 s) (Figure 1A). Aerosolised ECAS $(120 \mathrm{~s})$ also showed a significant reduction $(p<0.01)$ in total bacterial load when compared with aerosolised water (120 s); however, no significant reduction was shown for the $60 \mathrm{~s}$ treatment group (Figure 1A).

Table 1. Effect of sanitisation treatments on reduction of total bacterial load on egg surface.

\begin{tabular}{cccc}
\hline Treatment & $\begin{array}{c}\text { Total Bacterial Count } \\
\left(\mathbf{L o g}_{\mathbf{1 0}} \text { CFU/Egg) }\right.\end{array}$ & Log Reduction \& & $\begin{array}{c}\text { Significance } \\
(\boldsymbol{p} \text {-Value })\end{array}$ \\
\hline Untreated control & $2.2 \pm 0.2$ & - & - \\
NaOCl (45 s spray) & 0 & 2.2 & $<0.0001$ \\
Water (45 s spray) & $2.4 \pm 0.1$ & $(+0.2)$ & 0.3662 \\
ECAS (45 s spray) & 0 & 2.2 & $<0.0001$ \\
Water fog (60 s) & $2.5 \pm 0.2$ & $(+0.3)$ & 0.1201 \\
ECAS fog (60 s) & $2.1 \pm 0.1$ & 0.1 & 0.9206 \\
Water fog (120 s) & $2.3 \pm 0.2$ & $(+0.1)$ & 0.9895 \\
ECAS fog (120 s) & $0.8 \pm 0.6$ & 1.4 & 0.01 \\
\hline
\end{tabular}

Total bacterial counts were calculated as $\log _{10}$ CFU/egg and presented as mean \pm standard deviation (SD); ${ }^{\&} \log _{10}$ reduction $=\left(\log _{10}\right.$ counts of untreated control $)$ - $\left(\log _{10}\right.$ counts after sanitising treatment $) ; \mathrm{a}$ ' + ' sign means log increase in counts.

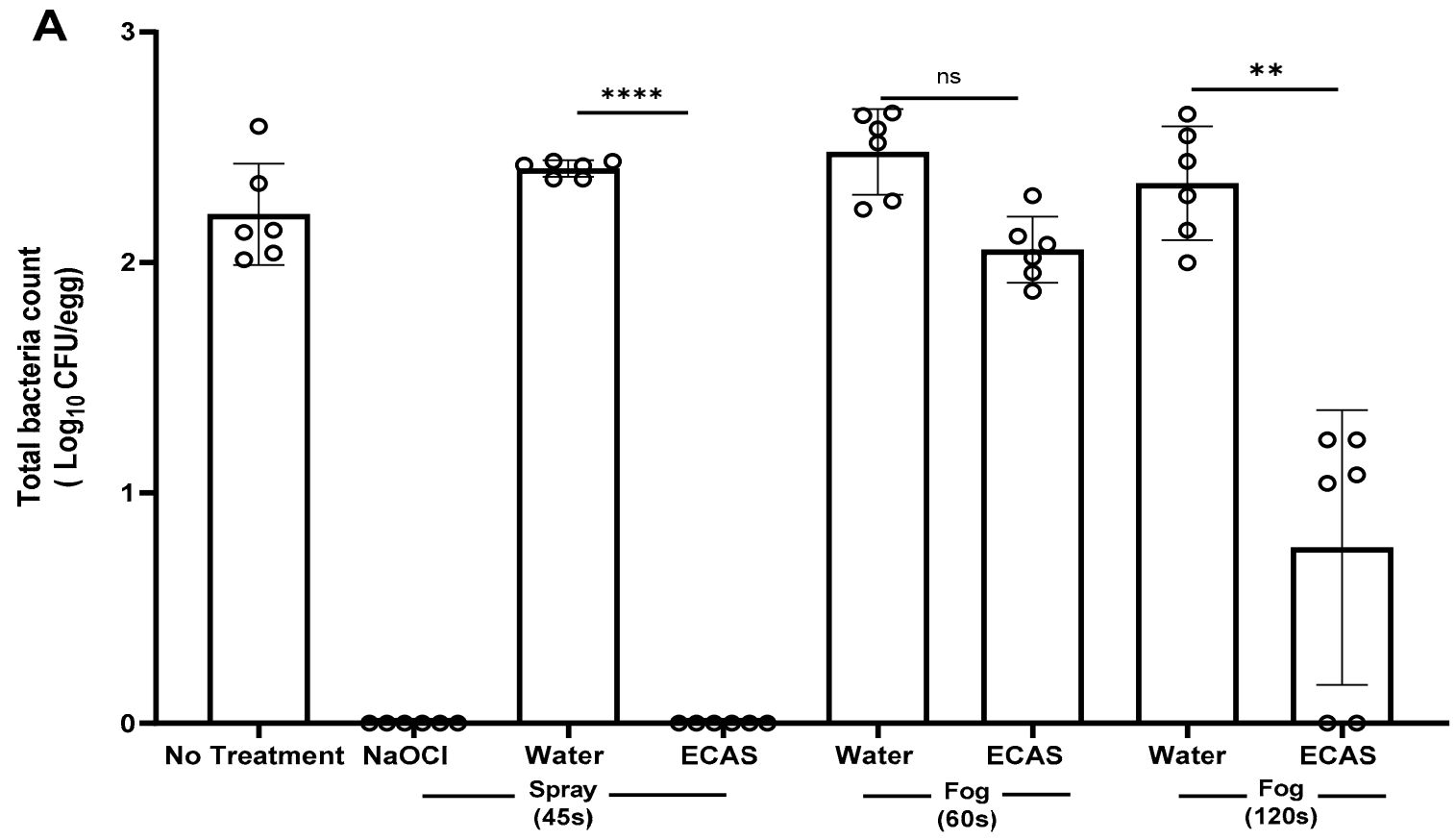

Sanitisation Treatment

Figure 1. Cont. 


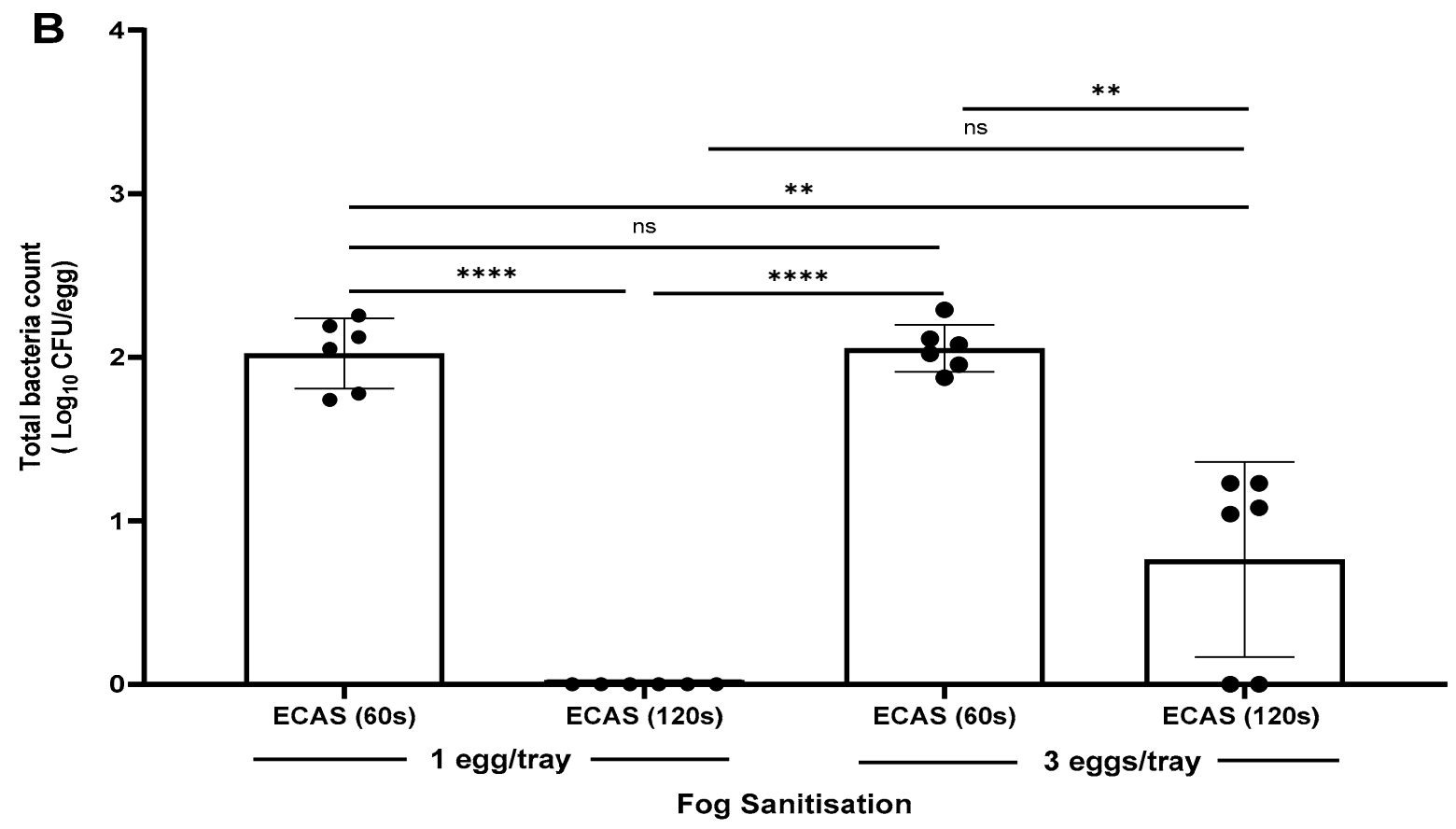

Figure 1. Effectiveness of sprayed and aerosolised ECAS on reduction of total bacterial load on egg surface. (A) Total bacterial load after the various sanitisation treatments. (B) Aerosolised ECAS sanitisation of individual (one egg/tray) and simultaneous (three eggs/tray) treated eggs for $60 \mathrm{~s}$ and $120 \mathrm{~s}$. NaOCl—sodium hypochlorite ( 200 mg/L FAC); ECAS—electrochemically activated solution (150 mg/L of FAC); ns—not significant; ${ }^{* *} p<0.01,{ }^{* * * *} p<0.0001$.

The effectiveness of aerosolised ECAS was further assessed when the eggs were sanitised simultaneously (three eggs/tray) or individually (one egg/tray) for $60 \mathrm{~s}$ and $120 \mathrm{~s}$, respectively. Aerosolised ECAS (120 s) significantly reduced the total bacteria load for both one egg/tray $(p<0.0001)$ and three eggs/tray $(p<0.01$; Figure 1B). The treatment of three eggs/tray with aerosolised ECAS (120 s) did not eliminate the total bacterial load completely; however, the level was not significantly different from the treatment of one egg/tray aerosolised ECAS (120 s) (Figure 1B).

\subsection{ECAS Spray and Fog Treatment Reduced S. Enteritidis on the Egg Surface}

$S$. Enteritidis counts $\left(\log _{10} \mathrm{CFU} / \mathrm{egg}\right)$ are presented in Table 2 and Figure 2. Sprayed water (45 s) showed a significant reduction (1.0 log reduction, $p=0.0005$; Table 2) when compared with the untreated control. All the ECAS treatments significantly reduced the inoculated $S$. Enteritidis counts on the egg surfaces compared to the untreated control: sprayed ECAS (45 s) (5.4 log reduction, $p<0.0001$; Table 2), aerosolised ECAS (60 s) (2.8 log reduction, $p=0.0008$; Table 2 ) and aerosolised ECAS (120 s) (4.2 log reduction, $p=0.0022$; Table 2). A significant reduction in $S$. Enteritidis counts $(1.1 \log$ reduction, $p<0.0001)$ was also achieved with aerosolised water $(120 \mathrm{~s})$, whereas no significant reduction was observed with aerosolised water (60 s) when compared with the untreated control (Table 2). For the spray versus aerosol techniques comparison, sprayed ECAS (45 s) showed a significant reduction $(p<0.0001)$ in $S$. Enteritidis load when compared with the sprayed water $(45 \mathrm{~s})$ (Figure 2A). Significant reduction in $S$. Enteritidis load was observed for aerosolised ECAS $(60 \mathrm{~s}, p<0.01)$ and aerosolised ECAS (120 s, $p<0.01)$ when compared with respective aerosolised water treatments (Figure 2A). S. Enteritidis level was significantly reduced in spray water (45 s, $p=0.0005)$ and aerosolised water treatment groups $(120 \mathrm{~s}, p<0.0001)$, respectively. 


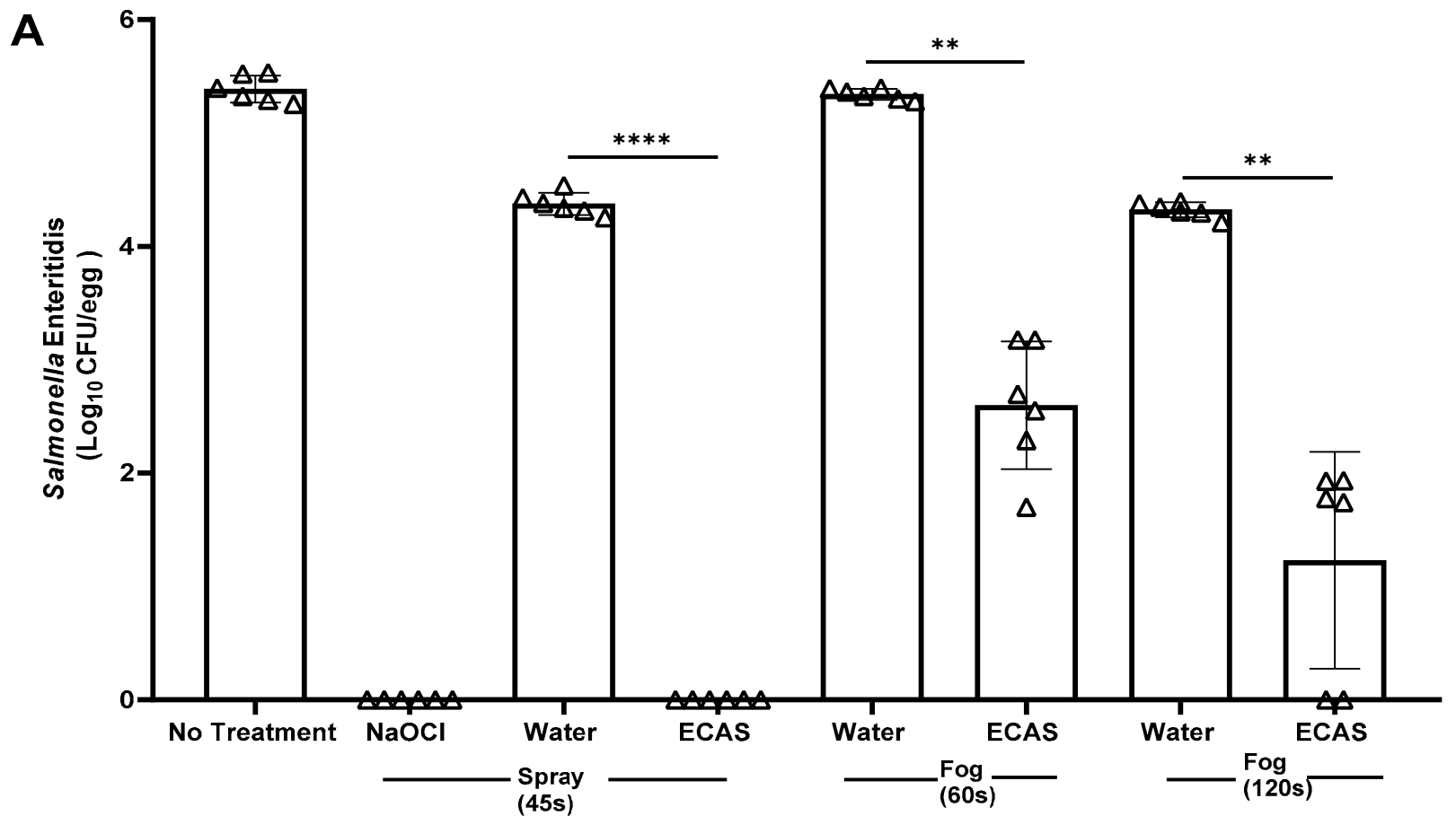

Sanitisation Treatment

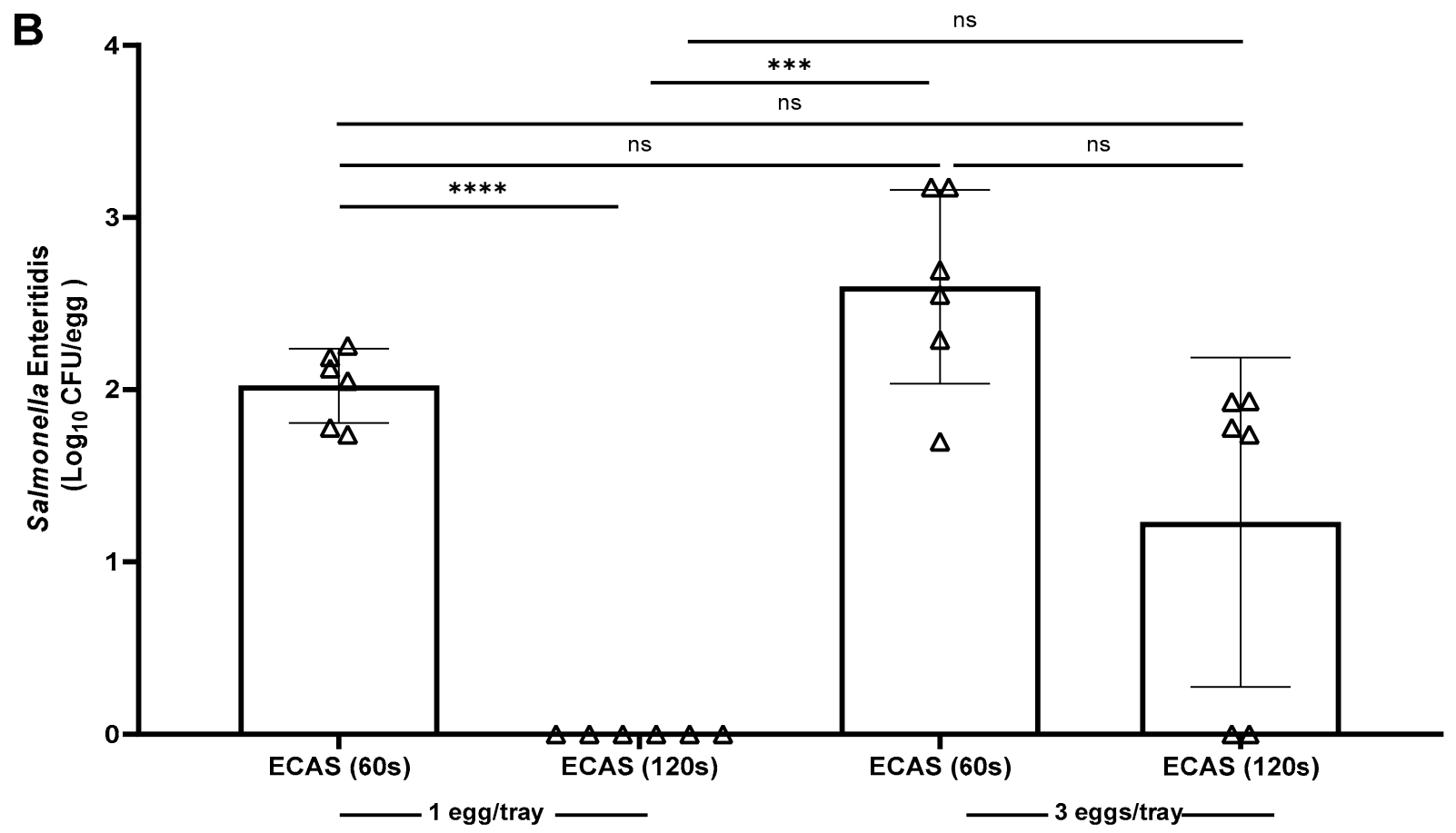

Fog Sanitisation

Figure 2. Effectiveness of sprayed and aerosolised ECAS on reduction of $S$. Enteritidis counts. (A) $S$. Enteritidis counts after the various sanitisation treatment. (B) Aerosolised ECAS sanitisation of individual (one egg/tray) and simultaneous (three eggs/tray) treated eggs for $60 \mathrm{~s}$ and $120 \mathrm{~s}$. NaOCl—sodium hypochlorite ( 200 mg/L FAC); ECAS—electrochemically activated solution (150 mg/L of FAC); ns-not significant; ${ }^{* *} p<0.01,^{* * *} p<0.001,{ }^{* * * *} p<0.0001$. 
Table 2. Effect of sanitisation treatments on the reduction level of $S$. Enteritidis counts on egg surface.

\begin{tabular}{cccc}
\hline Treatment & $\begin{array}{c}\text { S. Enteritidis Counts } \\
\left(\log _{\mathbf{1 0}} \text { CFU/Egg) }\right.\end{array}$ & Log Reduction \& & $\begin{array}{c}\text { Significance } \\
(\boldsymbol{p} \text {-Value })\end{array}$ \\
\hline Untreated control & $5.4 \pm 0.1$ & - & - \\
NaOCl spray (45 s) & 0 & 5.4 & $<0.0001$ \\
Water spray (45 s) & $4.4 \pm 0.1$ & 1.0 & 0.0005 \\
ECAS spray (45 s) & 0 & 5.4 & $<0.0001$ \\
Water fog (60 s) & $5.3 \pm 0.1$ & 0.1 & 0.9926 \\
ECAS fog (60 s) & $2.6 \pm 0.6$ & 2.8 & 0.0008 \\
Water fog (120 s) & $4.3 \pm 0.7$ & 1.1 & $<0.0001$ \\
ECAS fog (120 s) & $1.2 \pm 1.0$ & 4.2 & 0.0022 \\
\hline
\end{tabular}

S. Enteritidis counts calculated as $\log _{10}$ CFU/egg and presented as mean \pm standard deviation (SD); ${ }^{\&} \log _{10}$ reduction $=\left(\log _{10}\right.$ counts of untreated control $)-\left(\log _{10}\right.$ counts after sanitising treatment $)$.

Aerosolised ECAS (120 s) significantly reduced S. Enteritidis counts for one egg/tray $(p<0.0001)$; however, no significant reduction trend was observed in the 3 eggs/tray treatment group (Figure 1B).

\subsection{ECAS Spray and Aerosol Treatments Did Not Affect Egg Cuticle Integrity}

The effect of sprayed and aerosolised ECAS treatments on cuticle coverage $\left(\Delta E_{\mathrm{ab}}{ }^{*}\right)$ was measured (Figure 3). Sprayed ECAS (45 s) and aerosolised ECAS (120 s) did not show any significant difference when compared with the respective water controls.

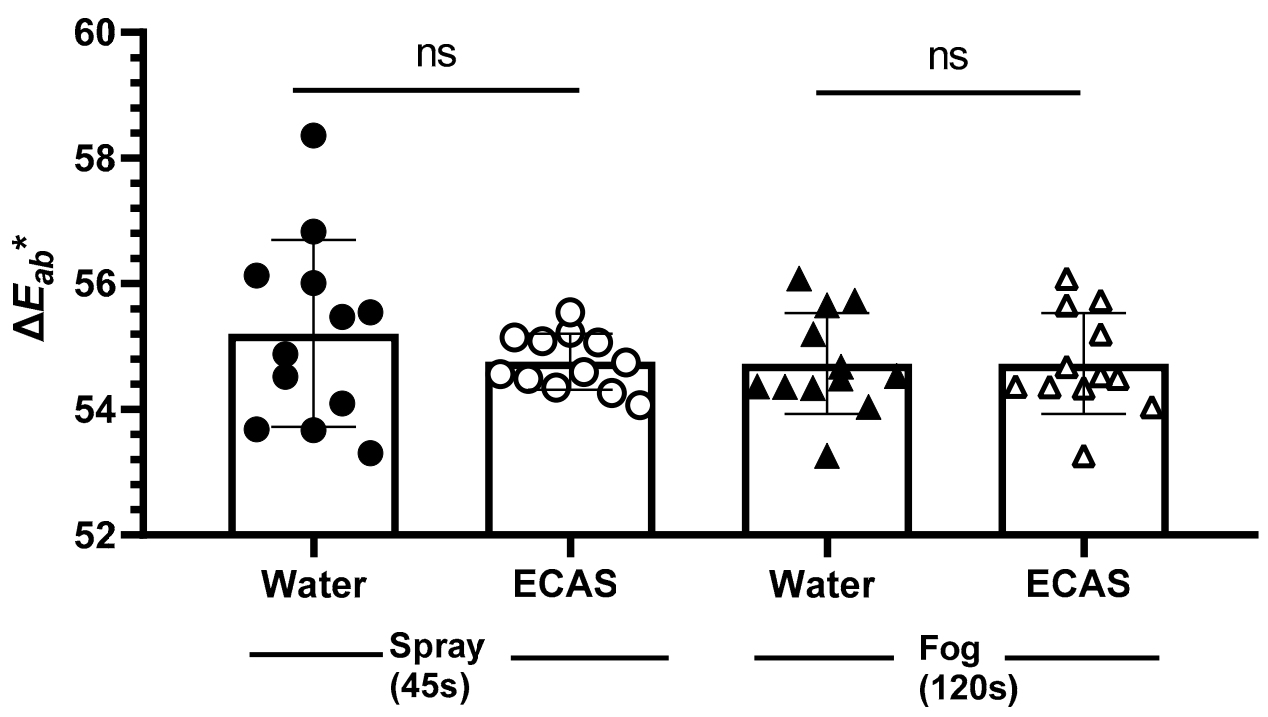

\section{Sanitisation Treatment}

Figure 3. Effect of sprayed and aerosolised ECAS treatments on cuticle integrity $\left(\Delta E_{\mathrm{ab}}{ }^{*}\right)$. Data presented as mean $\pm \mathrm{SD}, \mathrm{n}=12$; ns-not significant.

\section{Discussion}

This study assessed the effectiveness of sprayed and aerosolised ECAS in reducing total bacterial load and inoculated $S$. Enteritidis on egg surface and their effects on the cuticle layer. The bacterial load on eggshells is usually acquired through contamination from the farm environment; therefore, farm type and poultry housing system influence the egg surface total bacterial count [31-34]. Eggshells from conventional-caged hens usually harbour lower total bacterial counts compared to other housing systems [35]. The total bacterial load of $2.2 \pm 0.2 \log _{10} \mathrm{CFU} / \mathrm{egg}$ found in this study was lower than those observed by Wall et al. [36] $\left(2.7 \log _{10}\right)$ and Alvarez-Fernandez et al. [31] $\left(2.3 \log _{10}\right)$ on eggshells from conventional-caged hens, probably because the eggs used in this study were laid by hens housed individually with a low density of hens in the shed ( 49 hens/shed). 
ECAS spray-wash of eggs for $45 \mathrm{~s}$ and aerosolisation of individual eggs with ECAS for 120 s completely reduced the native total bacterial load and $S$. Enteritidis on eggshell surface. These two sanitisation approaches showed an effectiveness like that of a sodium hypochlorite ( $200 \mathrm{mg} / \mathrm{L}$ of FAC) spray-wash for $45 \mathrm{~s}$, which was used as a positive control. Although relevant literature is not available on the sanitisation of eggshell surface with ECAS fog, previous research has shown a significant reduction in total bacterial counts from the eggshell surface when the latter is spray-washed with $\mathrm{pH}$-neutral EO water or acidic EO water [22,37]. In the present study, the effectiveness of aerosolised ECAS with one and three eggs per oscillating tray for $60 \mathrm{~s}$ and $120 \mathrm{~s}$ was also tested. ECAS fogging of multiple eggs (three simultaneously) as well as of a single egg for $120 \mathrm{~s}$ showed a significant reduction in total bacterial load when compared with the respective $60 \mathrm{~s}$ treatments, confirming that a longer treatment time may be more appropriate for total bacteria load reductions. It is noteworthy that a higher variation was observed in treating three eggs simultaneously, which could be attributed to an uneven distribution of the fog, as fogging was performed in a biological safety cabinet that quickly sucked out the surrounding air including the fog.

Previous studies have assessed the effectiveness of various forms of electrolysed water (acidic, slightly acidic, neutral, alkaline) by immersion or spray-washing of eggshell surface inoculated with $S$. Enteritidis [24,38-40]. In this study, we assessed a pH-neutral EO water in the form of fog in addition to spray-washing. The significant microbial reduction observed in our study for sprayed water and aerosolised water $(120 \mathrm{~s})$ could be due to the dislodgment of the inoculated $S$. Enteritidis from the egg surface; however, these techniques were ineffective in the reduction of total bacterial load. Sprayed ECAS (45 s) and aerosolised ECAS (60 s and $120 \mathrm{~s}$ ) showed significant reduction in $S$. Enteritidis counts. Medina-Gudino et al. [24] reported that pH-neutral EO spray treatment (30 s) significantly reduced $S$. Enteritidis $\left(>1.45 \log _{10} \mathrm{CFU} / \mathrm{egg}\right)$ on egg surface. In another study [39], a slightly acidic ( $\mathrm{pH}$ 6.53) EO water (15 mg/L of FAC) used at 20 and $45{ }^{\circ} \mathrm{C}$ showed a $4.2 \log _{10} \mathrm{CFU} / \mathrm{mL}$ reduction of $S$. Enteritidis. Aerosolised ECAS (120 s) showed a significant $\log$ reduction of $S$. Enteritidis for one egg/tray treatment but no significant reduction was observed in the three eggs/tray treatment group. As previously mentioned, the higher variation in the three eggs/tray treatment could be due to the fog being quickly sucked by the BSC and not moistening the egg surface with enough FAC to reduce the bacterial cells.

The main purpose of egg washing is to reduce the bacterial load on the egg surface; however, one of the major concerns in the egg washing process is the likely damage of the cuticle layer. In the present study, no difference was observed in $\Delta E_{\mathrm{ab}}{ }^{*}$ values in eggs sprayed and aerosolised with ECAS, indicating that cuticle integrity was not altered. In a recent study, Medina-Gudino et al. [24] reported no differences in the overall $\Delta E_{\mathrm{ab}}{ }^{*}$ values when eggs were treated with $\mathrm{pH}$-neutral EO. In contrast, for eggs washed with alkaline and acidic EO, changes in the $a^{*}$ and $b^{*}$ values were observed, hence the reduction in overall $\Delta E_{\mathrm{ab}}{ }^{*}$ values, indicating damage to the egg cuticle [19].

Although electrolysed water is an environmentally friendly, non-hazardous sanitiser with proven antibacterial efficacy against foodborne pathogens such as E. coli O157: H7, L. monocytogenes [41] and S. Enteritidis on shell eggs [38,39], it is not currently being considered in commercial decontamination settings to obtain pathogen-free eggs. The reasons for this are probably related to the corrosiveness of acidic formulations towards steel surfaces and the lack of knowledge of consumers on the impact of chemicals for disinfection of environments.

The current scenario shows a shift in table egg production towards free-range systems [42]. For instance, in Australia, free-range production has increased from 39\% in 2015 to $45 \%$ in 2018 [10], driven by consumer demand for bird welfare and access to a range area. However, this approach poses risks to public health as the eggshell bacterial load, including counts of Campylobacter and Salmonella spp. [42], in free range production systems is considerably higher than in conventional battery cage systems [42,43]. The problem is further aggravated by the increase in the consumption of meals consisting of 
raw egg products [44]. Therefore, egg producers should consider eggshell cleaning and disinfection of table eggs as a priority to produce safe eggs and maintain consumer confidence. Besides issues with wastewater disposal, commonly used chlorine-based egg washing requires intensive monitoring of water temperature, $\mathrm{pH}$, and chlorine concentration to retain its optimal efficacy and eggshell cuticle integrity. This suggests that electrolysed water could fill an important niche if washing and disinfection systems can be developed on a commercial level.

\section{Conclusions}

pH-neutral ECAS (150 mg/L of FAC), when used in the form of a spray (45 s) or as an aerosol (120 s), allows significant reductions in total bacterial load and $S$. Enteritidis counts from contaminated egg surface while retaining cuticle integrity. However, aerosolised ECAS (60 s) did not show significant reduction in either the total bacterial load or $S$. Enteritidis counts, suggesting a longer fogging time is needed to sanitise the eggs. The aerosolised ECAS sanitisation technique could be incorporated into cleaning and disinfection protocol to improve egg safety without the use of hazardous biocidal agents. Moreover, this disinfection protocol is easily implementable as ECAS can be easily generated on site with automated controls for FAC concentration and $\mathrm{pH}$ measurements. For this process to lead to large-scale tests and industrial implementation, additional testing needs to be performed, including the elimination of other pathogenic bacteria from eggshells, interior egg quality and consumer sensory evaluation, as per the regulatory requirements.

Author Contributions: Conceptualization, S.T., P.D., D.J.T.; Methodology, S.T., S.K., P.D.; Formal analysis, S.T., P.D.; Resources, S.F., S.K., P.D., D.J.T.; Data curation, S.T.; Writing一original draft preparation, S.T., P.D.; Writing-review and editing, S.T., S.F., S.K., P.D., D.J.T.; Visualization, S.T.; Supervision, P.D., D.J.T.; Funding acquisition, D.J.T. All authors have read and agreed to the published version of the manuscript.

Funding: S.T. was supported by the Endeavour Postgraduate Scholarship.

Conflicts of Interest: The Authors declare no conflict of interest.

\section{References}

1. Kirk, M.; Ford, L.; Glass, K.; Hall, G. Foodborne Illness, Australia, circa 2000 and circa 2010. Emerg. Infect. Dis. 2014, 20, 1857-1864. [CrossRef] [PubMed]

2. NNDSS, National Notifiable Diseases. Australia's notifiable diseases status 2015: Annual report of the National Notifiable Diseases Surveillance System. Commun. Dis. Intell. 2019, 43. [CrossRef]

3. Painter, J.A.; Hoekstra, R.; Ayers, T.; Tauxe, R.V.; Braden, C.R.; Angulo, F.J.; Griffin, P.M. Attribution of foodborne illnesses, hospitalizations, and deaths to food commodities by using outbreak data, United States, 1998-2008. Emerg. Infect Dis. 2013, 19, 407-415. [CrossRef] [PubMed]

4. Braden, C.R. Salmonella enterica serotype Enteritidis and eggs: A national epidemic in the United States. Clin. Infect Dis. 2006, 43, 512-517. [CrossRef] [PubMed]

5. Moffatt, C.R.; Musto, J.; Pingault, N.; Miller, M.; Stafford, R.; Gregory, J.; Polkinghorne, B.G.; Kirk, M.D. Salmonella Typhimurium and outbreaks of egg-associated disease in Australia, 2001 to 2011. Foodborne Pathog. Dis. 2016, 13, 379-385. [CrossRef] [PubMed]

6. Ford, L.; Moffatt, C.R.M.; Fearnley, E.; Miller, M.; Gregory, J.; Sloan-Gardner, T.S.; Polkinghorene, B.G.; Bell, R.; Franklin, N.; Williamson, D.A.; et al. The epidemiology of Salmonella enterica outbreaks in Australia, 2001-2016. Front. Sustain. Food Syst. 2018, 2, 86. [CrossRef]

7. Bélanger, P.; Tanguay, F.; Hamel, M.; Phypers, M. Foodborne Illness: An overview of foodborne outbreaks in Canada reported through outbreak summaries: 2008-2014. Can. Commun. Dis. Rep. 2015, 41, 254-262. [CrossRef]

8. Jackson, B.R.; Griffin, P.M.; Cole, D.; Walsh, K.A.; Chai, S.J. Outbreak-associated Salmonella enterica serotypes and food commodities, United States, 1998-2008. Emerg. Infect. Dis. 2013, 19, 1239-1244. [CrossRef]

9. Sasaki, Y.; Tsujiyama, Y.; Asai, T.; Noda, Y.; Katayama, S.; Yamada, Y. Salmonella prevalence in commercial raw shell eggs in Japan: A survey. Epidemiol. Infect. 2011, 139, 1060-1064. [CrossRef]

10. AECL. Annual Report 2017-2018. In Australian Egg Corporation Limited Annual Report 2017-18; Australian Egg Corporation: North Sydney, Australia, 2018.

11. Perry, J.J.; Rodriguez-Romo, L.A.; Yousef, A.E. Inactivation of Salmonella enterica serovar enteritidis in shell eggs by sequential application of heat and ozone. Lett. Appl. Microbiol. 2008, 46, 620-625. [CrossRef] 
12. Al-Ajeeli, M.N.; Taylor, T.M.; Alvarado, C.Z.; Coufal, C.D. Comparison of eggshell surface sanitization technologies and impacts on consumer acceptability. Poult. Sci. 2016, 95, 1191-1917. [CrossRef] [PubMed]

13. Langsrud, S.; Sundheim, G.; Borgmann-Strahsen, R. Intrinsic and acquired resistance to quaternary ammonium compounds in food-related Pseudomonas spp. J. Appl. Microbiol. 2003, 95, 874-882. [CrossRef]

14. Fernandez Marquez, M.L.; Burgos, M.J.; Pulido, R.P.; Gálvez, A.; López, R.L. Biocide tolerance and antibiotic resistance in Salmonella isolates from hen eggshells. Foodborne Pathog. Dis. 2017, 14, 89-95. [CrossRef]

15. Ridgway, H.F.; Olson, B.H. Chlorine resistance patterns of bacteria from two drinking water distribution systems. Appl. Environ. Microbiol. 1982, 44, 972-987. [CrossRef]

16. De Reu, K.; Grijspeerdt, K.; Herman, L.; Heyndrickx, M.; Uyttendaele, M.; Debevere, J.; Putirulan, F.F.; Bolder, N.M. The effect of a commercial UV disinfection system on the bacterial load of shell eggs. Lett. Appl. Microbiol. 2006, 42, 144-148. [CrossRef] [PubMed]

17. IARC. Formaldehyde, 2-Butoxyethanol and 1-tert-Butoxypropan-2-ol, in formaldehyde, 2-butoxyethanol and 1-tert-butoxypropan2-ol. IARC Monogr. Eval. Carcinog. Risks Hum. 2006, 88, 1-478.

18. Achiwa, N.; Nishio, T. The use of electrolyzed water for sanitation control of eggshells and GP center. Food Sci. Technol. Res. 2003, 9, 100-103. [CrossRef]

19. Bialka, K.L.; Demirci, A.; Knabel, S.J.; Patterson, P.H.; Puri, V.M. Efficacy of electrolyzed oxidizing water for the microbial safety and quality of eggs. Poult. Sci. 2004, 83, 2071-2078. [CrossRef]

20. Rivera-Garcia, A.; Santos-Ferro, L.; Ramirez-Orejel, J.C.; Agredano-Moreno, L.T.; Jimenez-Garcia, L.F.; Paez-Esquiliano, D.; Andrade-Esquivel, E.; Cano-Buendia, J.A. The effect of neutral electrolyzed water as a disinfectant of eggshells artificially contaminated with Listeria monocytogenes. Food Sci. Nutr. 2019, 7, 2252-2260. [CrossRef] [PubMed]

21. Zang, Y.T.; Bing, S.; Li, Y.J.; Shu, D.Q.; Huang, A.M.; Wu, H.X.; Lan, L.T.; Wu, H.D. Efficacy of slightly acidic electrolyzed water on the microbial safety and shelf life of shelled eggs. Poult. Sci. 2019, 98, 5932-5939. [CrossRef] [PubMed]

22. Fasenko, G.M.; O’Dea Christopher, E.E.; McMullen, L.M. Spraying hatching eggs with electrolyzed oxidizing water reduces eggshell microbial load without compromising broiler production parameters. Poult. Sci. 2009, 88, 1121-1127. [CrossRef] [PubMed]

23. Surdu, I.; Vatuiu, D.; Jurcoane, S.; Olteanu, M.; Vatuiu, I. The Antimicrobial Activity of Neutral Electrolyzed Water against Germs and Fungi from Feedstuffs, Eggshells and Laying Hen House. Rom. Biotechnol. Lett. 2018, 23, 13607-13614.

24. Medina-Gudiño, J.; Rivera-Garcia, A.; Santos-Ferro, L.; Ramirez-Orejel, J.C.; Agredano-Moreno, L.T.; Jimenez-Garcia, L.F.; PaezEsquiliano, D.; Martinez-Vidal, S.; Andrade-Esquivel, E.; Cano-Buendia, J.A. Analysis of neutral electrolyzed water anti-bacterial activity on contaminated eggshells with Salmonella enterica or Escherichia coli. Int. J. Food Microbiol. 2020, 320, 108538. [CrossRef] [PubMed]

25. Cheng, K.-C.; Dev, S.R.S.; Bialka, K.L.; Demirci, A. Electrolyzed oxidizing water for microbial decontamination of food. In Microbial Decontamination in the Food Industry; Elsevier: Amsterdam, The Netherlands, 2012; pp. 563-591. [CrossRef]

26. Guentzel, J.L.; Liang Lam, K.; Callan, M.A.; Emmons, S.A.; Dunham, V.L. Reduction of bacteria on spinach, lettuce, and surfaces in food service areas using neutral electrolyzed oxidizing water. Food Microbiol. 2008, 25, 36-41. [CrossRef] [PubMed]

27. Liao, L.B.; Chen, W.M.; Xiao, X.M. The generation and inactivation mechanism of oxidation-reduction potential of electrolyzed oxidizing water. J. Food Engineer. 2007, 78, 1326-1332. [CrossRef]

28. Tenzin, S.; Ogunniyi, A.D.; Khazandi, M.; Ferro, S.; Bartsch, J.; Crabb, S.; Abraham, S.; Deo, P.; Trott, D.J. Decontamination of aerosolised bacteria from a pig farm environment using a $\mathrm{pH}$ neutral electrochemically activated solution (Ecas4 anolyte). PLoS ONE 2019, 14, e0222765. [CrossRef] [PubMed]

29. Gole, V.C.; Chousalkar, K.K.; Roberts, J.R.; Sexton, M.; May, D.; Tan, J.; Kiermeier, A. Effect of egg washing and correlation between eggshell characteristics and egg penetration by various Salmonella Typhimurium strains. PLoS ONE 2014, 9, e90987. [CrossRef]

30. Chousalkar, K.K.; Roberts, J.R.; Sexton, M.; May, D.; Kiermeier, A. Effects of egg shell quality and washing on Salmonella Infantis penetration. Int. J. Food Microbiol. 2013, 165, 77-83. [CrossRef]

31. Alvarez-Fernandez, E.; Domínguez-Rodríguez, J.; Capita, R.; Alonso-Calleja, C. Influence of housing systems on microbial load and antimicrobial resistance patterns of Escherichia coli isolates from eggs produced for human consumption. J. Food Prot. 2012, 75, 847-853. [CrossRef]

32. De Reu, K.; Grijspeerdt, K.; Heyndrickx, M.; Zoons, J.; De Baere, K.; Uyttendaele, M.; Debevere, J.; Herman, L. Bacterial eggshell contamination in conventional cages, furnished cages and aviary housing systems for laying hens. Br. Poult. Sci. 2005, 46, 149-155. [CrossRef]

33. De Reu, K.; Grijspeerdt, K.; Messens, W.; Heyndrickx, M.; Uyttendaele, M.; Debevere, J.; Herman, L. Eggshell factors influencing eggshell penetration and whole egg contamination by different bacteria, including Salmonella enteritidis. Int. J. Food Microbiol. 2006, 112, 253-260. [CrossRef] [PubMed]

34. De Reu, K.; Rodenburg, T.B.; Grijspeerdt, K.; Messens, W.; Heyndrickx, M.; Tuyttens, F.A.; Sonck, B.; Zoons, J.; Herman, L. Bacteriological contamination, dirt, and cracks of eggshells in furnished cages and noncage systems for laying hens: An international on-farm comparison. Poult. Sci. 2009, 88, 2442-2448. [CrossRef]

35. Dukic-Stojcic, M.; Peric, L.; Bjedov, S.; Milosevic, N. The quality of table eggs produced in different housing systems. Biotechnol. Anim. Husbandry. 2009, 25, 1103-1108. 
36. Wall, H.; Tauson, R.; Sorgjerd, S. Bacterial contamination of eggshells in furnished and conventional cages. J. App. Poult.Res. 2008, 17, 11-16. [CrossRef]

37. Ni, L.; Cao, W.; Zheng, W.-C.; Chen, H.; Li, B.-M. Efficacy of slightly acidic electrolyzed water for reduction of foodborne pathogens and natural microflora on shell eggs. Food Sci. Technol. Res. 2014, 20, 93-100. [CrossRef]

38. Park, C.-M.; Hung, Y.C.; Lin, C.S.; Brackett, R.E. Efficacy of electrolyzed water in inactivating Salmonella enteritidis and Listeria monocytogenes on shell eggs. J. Food Prot. 2005, 68, 986-990. [CrossRef] [PubMed]

39. Cao, W.; Zhu, Z.W.; Shi, Z.X.; Wang, C.Y.; Li, B.M. Efficiency of slightly acidic electrolyzed water for inactivation of Salmonella enteritidis and its contaminated shell eggs. Int. J. Food Microbiol. 2009, 130, 88-93. [CrossRef]

40. Venkitanarayanan, K.S.; Ezeike, G.O.; Hung, Y.C.; Doyle, M.P. Efficacy of electrolyzed oxidizing water for inactivating Escherichia coli O157:H7, Salmonella enteritidis, and Listeria monocytogenes. Appl. Environ. Microbiol. 1999, 65, 4276-4279. [CrossRef]

41. Park, H.; Hung, Y.C.; Chung, D. Effects of chlorine and $\mathrm{pH}$ on efficacy of electrolyzed water for inactivating Escherichia coli O157:H7 and Listeria monocytogenes. Int. J. Food Microbiol. 2004, 91, 13-18. [CrossRef]

42. Parisi, M.A.; Northcutt, J.K.; Smith, D.P.; Steinberg, E.L.; Dawson, P.L. Microbiological contamination of shell eggs produced in conventional and free-range housing systems. Food Control. 2015, 47, 161-165. [CrossRef]

43. De Reu, K.; Messens, W.; Heyndrickx, M.; Rodenburg, T.B.; Uyttendaele, M.; Herman, L. Bacterial contamination of table eggs and the influence of housing systems. World's Poult. Sci. J. 2008, 64, 5-19. [CrossRef]

44. Kretser, A.; Dunn, C.; DeVirgilis, R.; Perry, K.L. Utility of a new food value analysis application to evaluate trade-offs when making food selections. Nutr. Today. 2014, 49, 185-195. [CrossRef] 